\section{Why do we treat the children of Jehovah's Witnesses differently from their adult parents?}

\author{
Robert Wheeler
}

While many citizens may view an adult Jehovah's Witness' refusal of the blood transfusion that might otherwise save her life as irrational, the refusal alone does not lead the courts in England and Wales to conclude that she lacks competence. Her refusal will be considered competent, provided that she comprehends, believes and is able to weigh the information which is relevant to her decision and that she makes her choice free from coercion. The decision of a competent adult to refuse blood is legally binding on doctors. ${ }^{1}$ 'English law could not be clearer. A competent adult patient, once properly informed has the unassailable legal right to refuse any or all medical treatment or care'. ${ }^{2}$ This was amply demonstrated in the recent case of a 23 -year-old ${ }^{3}$ who had slashed his brachial artery. He was detained under the Mental Health Act 1983, and the court found that the artery could be repaired under the Act. However, he remained at risk of reopening his own wound. The court found that it would be '.. an abuse of power ...to even think about imposing a blood transfusion...' on a man with capacity to refuse blood products. The court also held that were his capacity to disappear, he had provided a valid advance decision to refuse blood transfusion.

This legal approach can be explained in part since the decision to refuse blood is not founded on any mental disability or dysfunction on the patient's behalf. Moreover, in more general policy terms, it would be unjust for the state to interfere in decisions based upon religious belief, since there is no reason why citizens should be deprived of their power to make decisions concerning only their own lives. $^{4}$

This principle of self-determination extends into decision-making in pregnancy. The competent and pregnant Jehovah's Witness may refuse the blood transfusion without which her unborn baby may die; in just the same way as she

Correspondence to Dr Robert Wheeler, Department of Paediatric Surgery, University Hospital Southampton, Tremona Road, Southampton SO16 6YD, UK; Robert.Wheeler@uhs.nhs.uk may refuse the emergency caesarean section $^{5}$ that provides the only chance that her baby may be born alive. Both refusals must be respected by her doctors, despite the impending loss of the child she carries, since the unborn baby has no legal personality, and its mother may choose for herself.

However, once the baby is separated from his mother, the situation is reversed. No longer will the law defer to a parent's wishes or religious beliefs if such deference will mean that the child is not treated in accordance with his best interests.

In the case ${ }^{6}$ of a 15 -year-old boy with leukaemia, a blood transfusion was required but his parents, Jehovah's Witnesses, refused to allow this. The local authority made him a ward of court and sought leave from the court to treat him. The judge held that the boy did not understand the effect of his refusal. He was under 16 years of age, and thus had not reached the statutory $^{7}$ presumption of capacity to consent. His parents' consent could be dispensed with, since his welfare was of paramount importance, notwithstanding the religious convictions of his family.

One year later, a court specifically considered the impact of Gillick competence on a similar case. The child ${ }^{8}$ in question was 14 years, critically injured and in need of a blood transfusion, which she refused because she was a Jehovah's Witness. At 14, English law presumed her to lack capacity, but the Gillick judgement ${ }^{9}$ provided her with the opportunity to prove that she was competent to consent for treatment, provided she could demonstrate her understanding and weighing of the relevant issues, and could communicate her decision.

However, the court found that while her religious beliefs were sincere, they had been formed during her sheltered upbringing within the Jehovah's community, rather than being developed through broad and informed experience of life. Furthermore, the court found that although she knew that she would die without transfusion, she had not been told of the likely 'gruesome' manner of her death. The effect of these two limitations in her decision-making was that she was found not to be Gillick competent, and in her best interests, transfusion in the absence of her consent was declared lawful. The court went further, noting that given the extremity of her clinical situation, the declaration would have been given even if she had demonstrated that she was competent.

This judgement was in keeping with a previous decision, ${ }^{10}$ relating to a 16 -yearold anorexic patient, but remaining at the heart of the English judicial approach to children (persons under the age of 18 yaers) pleading to be allowed to refuse lifesaving treatment:

No minor of whatever age has power, by refusing consent to treatment, to override a consent to treatment by someone who has parental responsibility for the minor....(or) a consent by the court.

The extent of the courts' powers was demonstrated in the case of a 15-year-old Jehovah's Witness ${ }^{11}$ who was refusing transfusion. The judge noted that the court '...should be very slow to allow an infant to martyr himself' and authorised the transfusion. Poignantly, it has become common knowledge that on attaining 18 years, E exercised his undoubted adult right to refuse blood products, and died of his anaemia.

Quite clearly, English courts have provided themselves with the authority to prevent citizens who are not yet 18 years from refusing life-saving treatment when it is readily available, in the case of Jehovah's Witnesses, blood product transfusion. However, it could be argued that it would be more honest to acknowledge, on occasion, that a person of this age is competent, and then simply overrule their wishes, rather than minutely to scrutinise their competence and find it wanting, to justify its avoidance.

Such an honest approach is clear in a decision concerning a 16-year-old Jehovah's Witness $^{12}$ with a hypermobility disorder. The application to allow transfusion of blood despite the refusal of the boy and his parents was made on a Friday, when he was not in need of urgent transfusion. But on the preceding Monday, he had been brought to hospital as an emergency, and the diagnosis of a dissecting aortic aneurysm had been contemplated and dismissed, but not before the Consultant treating him had resolved that '...blood transfusion...may well have been a futile gesture'. Accordingly, transfusion had been withheld, but mercifully had not been required. His presentation including 
a massively distended colon, which was likely the source of some modest blood loss, so the Trust sought the application due to the foreseeable need for future transfusion. The court made no attempt to view $\mathrm{P}$ as lacking capacity; on the contrary, the judge noted the young man's established religious convictions, and the importance of respecting them. He also noted approvingly the patient's assertion that his parent's view made no difference, and that he was making his own decision. There was no judicial hint that P's capacity was compromised by lack of experience or understanding.

The court found that there were '...weighty and compelling reasons why this order should not be made'. Nonetheless, the Trust was authorised to administer blood, but only if no other form of treatment was available.

In this way, although overruled, the patient's capacity was fully acknowledged, in a way that it had not been in the past.

An Anglican husband (a serving soldier) made an application to court ${ }^{13}$ to clarify and control the impact of his Jehovah's Witness wife's religious beliefs on his son. The court identified the central beliefs of Witnesses that could be relevant to a child's upbringing:

- 'A commitment to house-to-house evangelism, often with the children accompanying;

- A commitment to studying the Bible and attending Kingdom Hall meetings;

- Not celebrating Christmas, Easter or birthdays;

- Not allowing blood transfusions;

- To maintain a degree of separation from non-members, and not to engage in relationships with those of other faiths'.

The court noted that neither parent had the predominant right to selecting a child's religion, and that where parents followed different religions, the child should have the opportunity of exposure to both. For neither parent was the right to assert their religious influence unlimited. If the court found that the conflict caused by differing parental wishes over religious lifestyle was contrary to the child's welfare, then it was entitled to restrict the child's involvement in this lifestyle. They did not necessarily contravene the rights of the affected parent, provided that these restrictions were necessary for the child's welfare, and proportionate. However, on another occasion ${ }^{14}$ parental human rights have been breached when authorities have failed to investigate the specific welfare interests of the child of a Jehovah's Witness family. In this case, the decision makers instead had relied only on their general suppositions of the effect that the mother's religious beliefs might have had upon her child.

The court found that N's visits to Kingdom Hall should not be limited as his father had proposed, but did prohibit his parents from preventing him attend school activities such as nativity plays, concerts, clubs and school trips. If a blood transfusion was needed, N's mother was ordered to inform the relevant medical authorities that N's father was able to provide consent and to supply his contact details.

Whether or not there is public sympathy for parents whose religious views are at odds with transfusing blood into their desperately ill children, their position must not be automatically rejected. Our free society is predicated on tolerance, and this should be able to encompass deeply held religious conviction. But for many centuries, monarchs and then courts have exercised their parens patriae (parent of the nation) jurisdiction, protecting the incapacitated citizens unable to speak up for themselves. This remains deeply ingrained in our legal system, articulated by the inherent jurisdiction of the High Court. Thus when faced with a balancing act between the preservation of a child's life and respecting religious belief, it is unsurprising that many jurisdictions give life the priority, and give the child the deferred opportunity of making a competent adult decision when the time comes.

\section{Competing interests None}

Provenance and peer review Commissioned; externally peer reviewed.
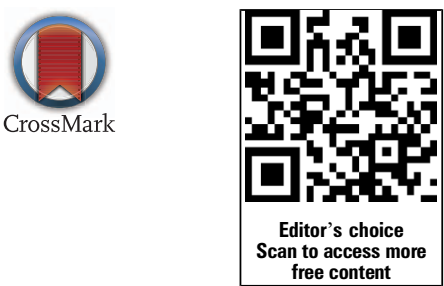

To cite Wheeler R. Arch Dis Child 2015;100:606607.

Received 8 December 2014

Revised 5 February 2015

Accepted 16 February 2015

Published Online First 4 March 2015

Arch Dis Child 2015;100:606-607.

doi:10.1136/archdischild-2014-307354

\section{REFERENCES}

1 Re T (Adult:Refusal of Treatment). 4 All ER 649 (CA) 1992.

2 Grubb A Medical Law Review. 201, 2002.

3 Nottinghamshire Healthcare NHST v RC. EWCOP 1317, 2104

4 Grubb A, Laing J Principles of Medical Law OUP, 3.83, 2004.

5 St George's Healthcare NHST v S. Fam 26 (CA), 1999

6 EE (A Minor). 1 FLR 386, 1993.

7 Family Law Reform Act, s8, 1969.

8 Re L (Medical Treatment: Gillick Competence). 2 FLR 810, 1998.

9 Gillick v West Norfolk \& Wisbech AHA. 3 All ER 402 1985.

10 Re W (A Minor) (Medical Treatment: Court's Jurisdiction). 3 WLR 758, 1992.

11 Re E (a minor), 2 FCR 219, 1992.

$12 \operatorname{Re} \mathrm{P}$ (Minor), EWHC 2327 (Fam), 2003.

13 Re N (A Child: Religion: Jehovah's Witness), EWHC 3737 (Fam), 2011.

14 Palau-Martinez v France, 2 FLR 810, 2004. 